\title{
Exploring Critical Success Factors in E-Learning Implementation
}

\author{
Kumar Raman, Norasmah Othman, Haryanti Mohd Affandi, Zanariah Hamid, Grace Danaraj
}

\begin{abstract}
Paper Setup must be in A4 size with Margin: Top 1.78 cm, Bottom $1.78 \mathrm{~cm}$, Left $1.78 \mathrm{~cm}$, Right $1.65 \mathrm{~cm}$, Gutter $0 \mathrm{~cm}$, and Gutter Position Top. Paper must be in two Columns after Authors Name with Width $8.59 \mathrm{~cm}$, Spacing $0.51 \mathrm{~cm}$. Whole paper must be with: Font Name Times New Roman, Font Size 10, Line Spacing 1.05 EXCEPT Abstract, Keywords (Index Term), Paper Tile, References, Author Profile (in the last page of the paper, maximum 400 words), All Headings, and Manuscript Details (First Page, Bottom, left side).Paper Title must be in Font Size 24, Bold, with Single Line Spacing. Authors Name must be in Font Size 11, Bold, Before Spacing 0, After Spacing 16, with Single Line Spacing. Please do not write Author e-mail or author address in the place of Authors name. Authors $e$-mail, and their Address details must be in the Manuscript details. Abstract and Keywords (Index Term) must be in Font Size 9, Bold, Italic with Single Line Spacing. All MAIN HEADING must be in Upper Case, Centre, and Roman Numbering (I, II, III...etc), Before Spacing 12, After Spacing 6, with single line spacing. All Sub Heading must be in Title Case, Left $0.25 \mathrm{~cm}$, Italic, and Alphabet Numbering $(A, B$, C...etc), Before Spacing 6, After Spacing 4, with Single Line Spacing. Manuscript Details must be in Font Size 8, in the Bottom, First Page, and Left Side with Single Line Spacing. References must be in Font Size 8, Hanging 0.25 with single line spacing. Author Profile must be in Font Size 8, with single line spacing. Fore more details, please download TEMPLATE HELP FILE from the website.
\end{abstract}

Index Terms: About four key words or phrases in alphabetical order, separated by commas.

\section{INTRODUCTION}

The integration of technology in education system has changed the traditional teaching and learning environment to the new learning style (Madina, 2014).The use of e-learning in education system has brought a huge revolution in how information is conveyed in the new generation (Bhuasiri, Xaymoungkhoun, Zo, Rho, \& Ciganek, 2012; Malik, 2010; Odunaike, Olugbara, Sunday O., \& Ojo, 2013; Vrana, Zafiropoulos, \& Drogalas, 2006) . After the revolution, e-learning could also create an efficient and attractive learning environment compared to the traditional ways (Madina, 2014).

In earlier stage, e-learning was known with various names such as, web-based learning (WBL), web-based instruction (WBI), web-based training (WBT), Internet-based training

\footnotetext{
Revised Manuscript Received on September 22, 2019. Kumar Raman, National University of Malaysia. kumarraman_71@yahoo.com

Norasmah Othman, National University of Malaysia Haryanti Mohd Affandi, National University of Malaysia

Zanariah Hamid, University of Malaya

Grace Danaraj, SK Putra Perdana.
}

(IBT), distributed learning (DL), advanced distributed learning, distance learning (DL), online learning (OL), mobile learning (m-learning), nomadic learning, remote learning and off-site learning (Madina, 2014). Khan (2005) defined e-learning as a student-centred innovation learning. However, Wagner, Hassanein, and Head (2008) and Govindasamy (2002) interpreted that e-learning is considered as a medium used to give instruction via electronic media such as internet, intranet, extranet, satellite television, audio/video tape, interactive TV, and CD-ROM. This statement is in line with Al-Homod and Shafi (2013), e-learning is an education system which used to convey information via IT. In addition, Mbarek and Zaddem (2013) said that e-learning is an instruction of teaching and learning $(\mathrm{T} \& \mathrm{~L})$ which is supported by using information communication technology (ICT) which enables the students to obtain new knowledge and skills at any time and at anywhere by using a variety of digital technology sources together with the relevant teaching materials. The summary of the e-learning definition is shown in Table 1. However, in this paper e-learning is defined as a medium used in teaching and learning sessions supported by the ICT application. It will enable students to obtain new knowledge and skills which will assist and increase the process of interactive teaching and learning among students and teachers.

\begin{tabular}{cl} 
& TABLE 1: E-LEARNING DEFINITION \\
\hline Authors & \multicolumn{1}{c}{ Definition } \\
\hline Khan (2005) & $\begin{array}{l}\text { E-learning is a student-centred innovation } \\
\text { learning. }\end{array}$ \\
Govindasamy &
\end{tabular}
(2002) and
E-learning is considered as a medium to give
Wagner et instructions via electronic media.

al. (2008)

Al-Homod \&

Shafi (2013)

E-learning is an education system which use to convey the information via IT sources and multimedia application.

E-learning is an instruction of $\mathrm{T} \& \mathrm{~L}$

Mbarek \&

Zaddem (2013) supported by ICT and enables the students to obtain new knowledge and skills at anytime and anywhere by using a variety of digital technology sources.

It can't be denied that the success of e-learning depends on various of important factors that will bring success to an inclusive e-learning project. Therefore, the Critical Success Factors (CSFs) are the foundation of success behind the implementation of e-learning. Frimpon (2012) suggests that the educational organizations should handle the CSFs properly to achieve their goals

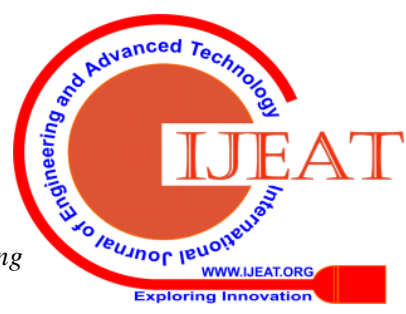


in the implementation of e-learning. Inview of this, the purpose of this research is to discover the effects of CSFs in e-learning implementation.

\section{LITERATURE REVIEW}

Based on statistic realesed by UNESCO. (2009), about 455 million people around the world received online education and training in 2008. In addition, more than 70 percent of universities in the United States offer e-learning education and 6.1 million students enrolled in a least one online course via in 2010 (Musa \& Othman, 2012). This represents the 31 percent of univeristy students in the United States (Zhang \& Cheng, 2012). The same scenario is occuring in Malaysia, where nearly 40 percent of courses in Malaysian universities are offering e-learning based courses with a student enrollment number of about 1.2 million (Helmi, 2002). Furthermore, many educational institutions in Malaysia are starting to combine traditional courses with e-learning innovations to save cost (Helmi, 2002). On top of that, the Ministry of Education Malaysia has invested nearly RM6 billion from 1999 to 2010 to integrate ICT into education through various ICT programs in schools (Ministry of Education Malaysia, 2012).

On the other hand, many e-learning projects have been abandoned and failed in the process of achieving their objectives (Frimpon, 2012; Mosakhani \& Jamporazmey, 2010). For instance, the UK e-University, NYU Online, Scottish Knowledge, University 21 and Global University Alliance (GUA) failed during the process of implementing e-learning (Garrett, 2004; Oliver, Herrington, \& Reeves, 2005; Oppenheimer, 2003; Romiszowski \& Sikorski, 2005). Surprisingly, in Malaysia only one third of teachers are using ICT in teaching and learning (T\&L) sessions and most of them only use Power Point presentations as their ICT influenced teaching tool (UNESCO, 2012). In addition, less than 80 percent of teachers are using ICT in a period of less than one hour per week in their teaching sessions (Ministry of Education Malaysia, 2012). Meanwhile, Malaysian Auditor General's report in 2013 revealed that the usage of Frog VLE application (another platform of e-learning in Malaysia) by teachers and students are very low, which was less than 4.69 percent (Ministry of Finance Malaysia, 2013; UNESCO, 2012). In view of this a deep understanding of CSFs of e-learning system will assist an organization to manage its funds in an efficient manner to ensure an successful e-learning implementation (Levy (2006).

CSFs are the limited number of factors which ensure the successful performance of an individual or organisation (Rockhart, 1979). According to Freund (1988), CSFs is defined as things that must be done in order for a company to be successful. Many researches have been conducted studies on e-learning but only some of the researches are significant to CSFs (Akhavan, Jafari, \& Fathian, 2006). Frimpon (2012) considered CSFs as a variable which became a base for a successful implementation of e-learning and companies that conduct a good CSFs will be almost definitely be successful.

\section{METHOdOLOGY}

The objective introduced in this paper is to identify the CSFs of success e-learning implementation by conducted literature analysis as per shown in Figure 1. The process of reviewing articles started with shortlisting previous studies based on the keywords, "Critical Success Factors for E-Learning". Each paper must be published in a peer-reviewed and/ archival journal. Since there is a large number of papers, only articles that discuss e-learning at "university" and / or "educational institutions" are taken into consideration for analysis. Finally, the articles with the keywords "Critical Success Factors" and/or "affecting factors" appeared in the title and / or abstract are also selected in this study. Out of 133 searching papers only 100 papers were selected for reviewing. The selected papers were reselected by reading the abstract of the papers. At the end of this prosess only 44 papers were selected (Appendix 1). The list of 44 selected papers along with the number of papers appeared in journal and conferences can be found in Appendix 2.

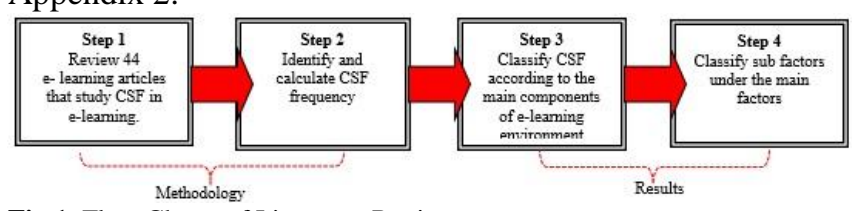

Fig 1. Flow Charts of Literature Review

\section{RESUlTS}

Based on the reviewed articles, found that many researchers have identified important factors to implement successful e-learning. For instant, H. S. Selim (2007) has that identified learner, instructor, information technology and organization's support was listed to achieve successful e-learning implementation. Apart from that, Frimpon (2012), has highlighted seventeen success factors which influence the use of e-learning and partitioned into four natural roles as follows: student, Instructor, Technology, and Institution. In addition, Sun, Tasi, Finger, Chen, and Yeh (2008) and Malik (2010) studies were similar to Selim's (2007) with an additional focus on technical aspects of e-learning. On the same token, Mosakhani and Jamporazmey (2010) have revealed that, student's and teacher's characteristics, information technology quality, content quality, learning environment and the institution's support as a CSFs for e-learning. Most of these studies have affirmed that human aspects of students and faculty members are the main critical factors behind the success of e-learning.

Previous studies have investigated the importance of CSFs in the application of e-learning. Alhomod and Shafi (2013); Chokri (2012); Presley and Presley (2009); Taha (2013) classified student's characteristics and the use of a variety of teaching integration technology are the main factors of successful e-learning implementation. Al-Fadhli (2008) synthesized that the teacher's dimension is a crucial factor which significantly influences the student's satisfaction in e-learning environment (Chen., Liao., \& Chen., 2010; Jan \& Contreras, 2011; Musa \& Othman, 2012; Owens \& Price, 2010; Sun et al., 2008; Wang \& Wang, 2009). 
Moreover, Pituch and Lee (2006) have identified that the effectiveness of technology plays an important role in influencing the user's acceptance of e-learning. This study is in line with Abbad, Morris, and De Nahlik (2009); Abu Sneineh and Zairi (2010); Al-Fadhli (2011); Masoumi (2006); Musa and Othman (2012); H. M. Selim (2007); Volery and Lord (2000), which shows that technology plays a signficant role in the success of e-learning implementation. On the other hand, the institution's support were classified as a vital factor which enhances the user's usage, satisfaction and acceptance of e-learning (Abdel-Wahab, 2008; Ahmed, 2010; Broadley, 2007; Goi \& Ng, 2009; Masoumi, 2006; Mosakhani \& Jamporazmey, 2010; H. M. Selim, 2007).

Content quality has positive influence on the users' satisfaction of e-learning (Al- Ammary \& Sharifa, 2008; Hassanzadeh, Kanaani, \& Elahi, 2012; Owens \& Price, 2010; Shee \& Wang, 2008; Sun et al., 2008). Additionally, Abdel-Wahab (2008), and Al- Ammary and Sharifa (2008) discussed that attitude has a positive relationship with preceived usefulness. User friendly interface is also one of the essential factors to encourage a positive feedback on the implementation of e-learning (Abdel-Wahab, 2008; AlAmmary \& Sharifa, 2008; Chen \& Tseng, 2012; Johnson, Hornik, \& Salas, 2008; Presley \& Presley, 2009; Wang \& Wang, 2009). Some of the previous studies showed that interactive collaboration is one of the main factors which determine the acceptance of e-learning (Goi \& Ng, 2009; Johnson et al., 2008; Mosakhani \& Jamporazmey, 2010; Musa \& Othman, 2012; H. M. Selim, 2007). Social presence, subjective norms, e-learning environment and knowledge management are also considered as important factors in influencing the acceptance in the implementation of e-learning. The break down of the CSFs are as follows;

\section{A. Teacher's Characteristics}

Some researchers have revealed that teachers play a vital role in ensuring a successful implementation of e-learning (Ahmed, 2010; Alhomod \& Shafi, 2013; Bhuasiri et al., 2012; FitzPatrick, 2012; Hassanzadeh et al., 2012; Nurul Islam, Martin Beer, \& Slack, 2015). This is compatible with Ali, Ramay, and Shahzad (2011), who stated that in an e-learning environment, the teachers are required to acquire a new set of skills that are relevant and related to the latest technology available to enhance their effectiveness in the teaching and learning process.

Chen. et al. (2010) who investigated the CSFs in e-learning among 46 adult students from National Open University, Taiwan reported that teacher's attitude such as friendliness and enthusiasm are the crucial factors which are able to influence students to have trust towards the e-learning project. Results from the studies conducted by Volery and Lord (2000), Govindasamy (2002) and Sun et al. (2008) also warrant evidences indicating that teacher's attitude and teaching styles play a vital role in efficient teaching and learning process. Moreover, in e-learning environment, student's acceptance and satisfaction are strongly dependent on teaching style and teacher-student interactions during teaching and learning sessions (Ali et al., 2011; Bhuasiri et al., 2012; FitzPatrick, 2012; McPherson \& Nunes, 2008; H. M. Selim, 2007; Volery \& Lord, 2000). Besides that, teacher's efficacy, readiness in negotiation and giving effective feedback on students' inquiry are also ensuring e-learning's success (Bhuasiri et al., 2012; Liaw, Huang, \& Chen, 2007; Wang \& Wang, 2009). The above findings were consistent with studies conducted by Malik (2010), Mosakhani and Jamporazmey (2010), Al-Fadhli (2011), Jan and Contreras (2011) and Fageeh (2011) on the effects of teacher characteristics in e-learning success. To sum up, many researchers who examined and investigated this topic have agreed and conclude that teacher's characteristics are a significant contributor to e-learning success. It should be highly considered and broadly discussed during the development of implementing e-learning to ensure its success and effectiveness.

\section{B. Student's Characteristics}

Vrana et al. (2006) and Ibrahim, Rwegasira, and Taher (2007) defined e-learning as an innovation of technology which provides an effective learning through meaningful interactions and communication between students and teachers. In line with this, Malik (2010), Fageeh (2011), Zewayed, Maynard, and Murray (2011), Frimpon (2012), Alhomod and Shafi (2013), Recep Cakir and Solak (2014), Abdullah and Toycan (2018) have conducted several studies to examine the influence of student's characteristics in e-learning implementation and disclosed that student's role is one of the CSFs in e-learning implementation. Student's positive attitude towards e-learning will enhance their satisfaction and increase the level of e-learning acceptance (Abbad et al., 2009; Liaw et al., 2007; Malik, 2010; Mosakhani \& Jamporazmey, 2010; Presley \& Presley, 2009; H. S. Selim, 2007; Sun et al., 2008). Abdel-Wahab (2008) and Presley and Presley (2009) agreed that student's attitude would contribute significantly to the success of the implementation on e-learning. Mosakhani and Jamporazmey (2010) and Chen and Tseng (2012) said that motivation controlled factor is also one of the vital factors for better e-learning implementation.

A survey conducted by Teo, Luan, Thammetar, and Chattiwat (2011) among 377 students at three public universities in Thailand revealed that students who had more confidence in using computers showed a higher level of e-learning acceptance. This finding is in line with Chen. et al. (2010), Abbad et al. (2009). The resulted from the studies conducted Mosakhani and Jamporazmey (2010), Al-Fadhli (2011), Frimpon (2012), Chokri (2012), Musa and Othman (2012) and Nurul Islam et al. (2015) also confirmed that computer efficacy and knowledge of using computer can essentially affect student's satisfaction in e-learning environment. Lack of computer knowledge will dampen their online experience and will lead them to not get most of the benefits of e-learning (H. M. Selim, 2007). Other than that, cultural and social norms are also equally important in practising e-learning (Al-Fadhli, 2011). Countries like Saudi Arabia restricting female student getting involved freely in online (Al-Fadhli, 2011). This caused the female students to have less confidence in expressing their ideas as male students in e-learning environment (Al-Fadhli, 
2011). In view of this, both cultural and social norms factors must take into consideration during the process of implementing e-learning.

\section{Information Technology Infrastructure}

Broadley (2007), H. M. Selim (2007), Sun et al. (2008), Wang and Wang (2009), Goi and Ng (2009), stated that information technology infrastructure is proven as a key factor to detemine the success of e-learning implimentation. This finding is supported by studies conducted by Ahmed (2010), Abu Sneineh and Zairi (2010), Mosakhani and Jamporazmey (2010), Owens and Price (2010), Al-Fadhli (2011), Bhuasiri et al. (2012), FitzPatrick (2012), Abdullah and Toycan (2018), who identified that, good accessibility and connectivity towords computers and internet are the common elements that influence teachers and students in utilizing ICT resources in teaching and learning sessions. Furthermore, the availability and reliability of information technology infrastructure are able to increases student's satisfaction on e-learning environment (Malik, 2010). In view of this, both availability and reliability of information technology infrastructure must be considered as vital factors in achieving successful e-learning implementation (Abu Sneineh \& Zairi, 2010 ; Al-Fadhli, 2011; Malik, 2010; Pituch \& Lee, 2006; H. M. Selim, 2007; Sun et al., 2008). This opinion is in line with a study by Owens and Price (2010) who stated that the technical variables towards perceived usefulness can predict the student's acceptance on e-learning system. In short, all technological infrastructure barriers must rectify to ensure successful e-learning (Abdullah \& Toycan, 2018).

\section{Design and content}

Several researchers have argued that beside teacher's characteristics, student's characteristics, and IT infrastructure, the design and content of the e-learning are also a crucial factor in implementing successful e-learning (Alhomod \& Shafi, 2013; Chokri, 2012; Fageeh, 2011; FitzPatrick, 2012; Fuad, Trayek, \& . 2013; Jan \& Contreras, 2011; Mosakhani \& Jamporazmey, 2010; Presley \& Presley, 2009; H. M. Selim, 2007; Sun et al., 2008). Therefore, the quality of design and content are important factors influencing teacher's and student's satisfaction in e-learning environment (Hassanzadeh et al., 2012). System's qualities refer to the stability, security, reliability, speed of response, ease of use, and user-friendliness. Zewayed et al. (2011) proposed that, perceived ease of use of technology determines the student's intention of using e-learning systems it does not require high computer skills and efficiency. Same goes to the content and the delivery process, they should be designed properly because an appropriate assistance is needed to assist students in using technology infrastructure which can increase their confidence in e-learning environment (Sun et al., 2008). Wang and Wang (2009) who conducted a survey among 268 university instructors agreed to this statement and discovered that perceived ease of use can increase perceived usefulness. These findings were consistent with several studies which revealed that perceived ease to use and perceived usefulness of e-learning system will motivate the teachers and students to continue using the system (Alhomod \& Shafi, 2013; Chokri,
2012; Fageeh, 2011; FitzPatrick, 2012; Fuad et al., 2013; Jan \& Contreras, 2011; Mosakhani \& Jamporazmey, 2010). In view of this both perceived ease of use and perceived usefulness are essential factors to determine teacher's and student's attitudes toward using e-learning system (Abdullah \& Toycan, 2018; Bhuasiri et al., 2012; Chen \& Tseng, 2012; Fuad et al., 2013; Jan \& Contreras, 2011; Owens \& Price, 2010). This is in line with a study by Friedrich (2010) who pointed out that perceived usefulness is a major predictor of student's acceptance towards e-learning.

\section{E. Organizational Characteristics}

Organization plays a vital role to ensuring success in e-learning environment (Al-Homod \& Shafi, 2013; Frimpon, 2012). Organization's commitments such as management support in the technical aspect, human resourses, training programs for users and ICT technicians are the most important aspects which play crucial roles in the success of e-learning imlimentation (Al-Homod \& Shafi, 2013; FitzPatrick, 2012). Furthermore, sufficient e-learning initiatives and availability of informatin on website must take into consideration (Abu Sneineh \& Zairi, 2010 ; Ahmed, 2010; Al-Homod \& Shafi, 2013; Frimpon, 2012; Mosakhani \& Jamporazmey, 2010). Moreover, the lack of technical advice and support from organization will lead to the failure of the e-learning projects (Ahmed, 2010; Al-Homod \& Shafi, 2013). In another words, organization's supports in both human and non human resouces are essential for e-learning's success (Abu Sneineh \& Zairi, 2010 ; Ahmed, 2010; Bhuasiri et al., 2012; Hassanzadeh et al., 2012; Mosakhani \& Jamporazmey, 2010; Nurul Islam et al., 2015). Organization's support is not only limited to technical assistance, but it covers all type of supports in order to make sure that the e-learning project becomes successful.

\section{FINDINGS}

Based on the literature analisis, five main factors and eighteen sub-factors were identified as a CSFs for successful e-learning implementation. The CSFs are teacher's characteristics (teacher's attitude, teacher's computing technical skills, interaction among teaches-students, teaching style, knowledge in e-learning content development and self-efficacy), student's characteristics (attitude, computer competency, interaction, self-efficacy, motivation and cultural and social norms), information technology infrastructure (internet accessibility, reliability and availability), design and content (perceived ease of use and perceived usefulness) and organization characteristics (training and support). A proposed coceptual framework was designed based on these CSFs as per shown in Figure 2. 


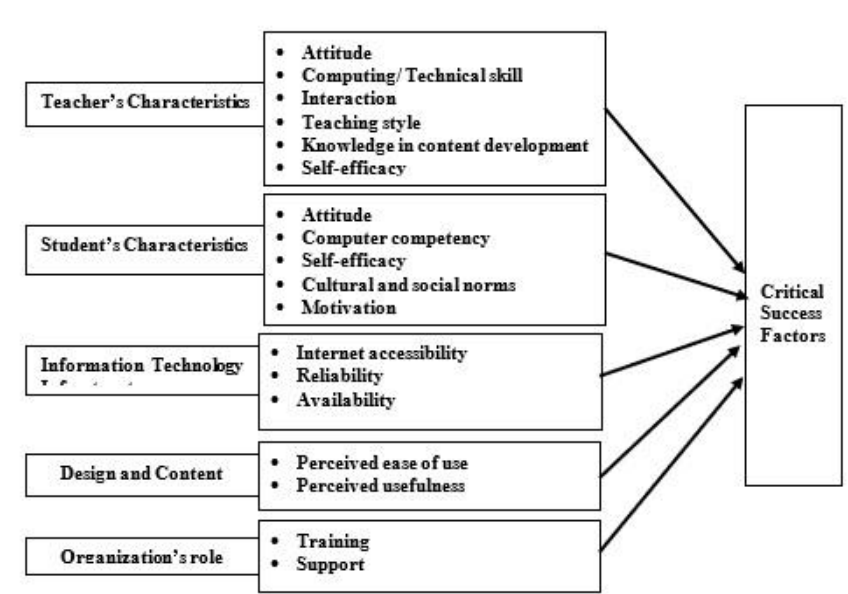

Fig 2. A Proposed Conceptual Framework on CSFs in e-Learning Implementation

\section{CONClusion}

In last two-decade e-learning has become a more popular way of study among students in the world. This trend can also be seen in higher education institution and schools where the students utilize the e-learning system to gain new knowledge and skills in their respective field of study. Although various initiatives have been taken to ensure the success of e-learning, but there are still several e-learning programs that do not meet their goals. Therefore, identifying CSFs is a big step towards determining the correct direction of a successful implementation of e-learning. It can be concluded that, CSFs is a variable and its characteristics should be considered carefully during the planning phase of e-learning, in order for the e-learning project to be implemented steadily. Hence, these CSFs must be verified, controlled and measured to determine the success of the entire e-learning system.

\section{REFERENCES}

[1] Abbad, M. M., Morris, D., \& De Nahlik, C. (2009). Looking under the bonnet: Factors affecting student adoption of e-learning systems in Jordan. The International Review of Research in Open and Distributed Learning. 10(2).

[2] Abdel-Wahab, A. G. (2008). Modeling students' intention to adopt e-learning a case from Egypt. . Turkish Online Journal of Distance Education, 9(1).

[3] Abdullah, M. S., \& Toycan, M. (2018). Analysis of the Factors for the Successful E-Learning Services Adoption from Education Providers' and Students' Perspectives: A case study of Private Universities in Northern Iraq. . EURASIA Journal of Mathematics, Science and Technology Education., 14(13), 1097-1109.

[4] Abu Sneineh, W., \& Zairi, M. (2010 ). An evaluation Framework for E-learning Effectiveness in The Arab World. International Encyclopedia of Education, 521-535. Learner Perceptions. Decision Sciences Journal of Innovative Education . 8(2)

[6] Akhavan, P., Jafari, M., \& Fathian, M. (2006). Critical success factors of knowledge management systems: a multi-case analysis. European Business Review, 18(2), 97-113.

[7] Al- Ammary, J., \& Sharifa, H. (2008). Factors Influencing the Adoption of E-learning at UOB. Paper presented at the Proceeding of the Second International Conference and Exhibition for Zain e-Learning Center Manama, Bahrain.

[8] Al-Fadhli, S. (2008). Students' Perceptions of E-learning in Arab Society: Kuwait University as a case study. E-Learning and Digital Media, 5(4), 418-428.

[9] Al-Fadhli, S. (2011). Factors Influencing the Acceptance of Distance-Learning: A Case Study of Arab Open University in Kuwait. International Journal of Instructional Media, 38(2).

[10] Al-Homod, S., \& Shafi, M. M. (2013). Success Factors of E-learning Projects: A Technical Perspective. The Turkish Online Journal of Educational Technology, 12(22), 247-253.
[5] Ahmed, H. M. S. (2010). Hybrid E-Learning Acceptance Model:

[11] Alhomod, S., \& Shafi, M. M. (2013). Success Factors of E-Learning Projects: A Technical Perspective. Turkish Online Journal of Educational Technology-TOJET, 12(2), 247-253.

[12] Ali, A., Ramay, M. I., \& Shahzad, M. (2011). Key factors for determining students' satisfaction in distance learning courses: A study of Allama Iqbal Open University. Contemporary Educational Technology, 2(2), 118-134.

[13] Bhuasiri, W., Xaymoungkhoun, O., Zo, H., Rho, J. J., \& Ciganek, A. P. (2012). Critical success factors for e-learning in developing countries: A comparative analysis between ICT experts and faculty Computers and Education, 58, 843-855.

[14] Broadley, T. (2007). Implementation of E-Learning: A Case Study of Three Schools. Curtin University of Technology www.academia.edu

[15] Chen, H.-R., \& Tseng, H.-F. (2012). Factors that influence acceptance of web-based elearning systems for the in-service education of junior high school teachers in Taiwan. Evaluation and Program Planning,, 35 , 398-406.

[16] Chen., F. S., Liao., C. W., \& Chen., T. H. (2010). Notice of Retraction Adult Distance Education Students' Perspective on Critical Success Factors of e-Learning. . Paper presented at the International Conference on Education Technology and Training (ETT 2009) (ETT) Sanya.

[17] Chokri, B. (2012). Factors Influencing the Adoption of the E-Learning Technology in Teaching and Learning by Students of a University Class. European Scientific Journal 8(28), 165-190.

[18] Fageeh. (2011). ELF students' readiness for e-learning: factors influencing e-learners' acceptance of the Blackboard in a Saudi university. The JALT CALL Journal, 7(1), 19-42.

[19] FitzPatrick, T. (2012). Key success factors of eLearning in education: A professional development model to evaluate and support eLearning. Retrieved

from http://search.ebscohost.com/login.aspx?direct=true $\& \mathrm{db}=$ eric\&AN=E D537174\&site=eds-live.

[20] Freund, Y. P. (1988). Critical success factors. Planning Review, 16(4), 20-23.

[21] Friedrich, H. F., and Hron, A. . (2010). Factors influencing pupils' acceptance of an e-learning system for secondary schools. Journal of Educational Computing Research,, 42(1), 63-78.

[22] Frimpon, M. (2012). A Re-Structuring of the Critical Success Factors for E-Learning Deployment. American International Journal of Contemporary Research, 2(3).

[23] Fuad, A. A., Trayek, \& ., S. S. S. H. (2013). Attitude towards the use of learning management system among university students: A case study. Turkish Online Journal of Distance Education,, 14(3), 91-103.

[24] Garrett, R. (2004). The real story behind the failure of the UK eUniversity. Educause Quarterly, 4, 3-6.

[25] Goi, C., \& Ng, P. Y. (2009). E-learning in Malaysia: Success factors in implementing e-learning program. International Journal of Teaching and Learning in Higher Education, 20(2).

[26] Govindasamy, T. (2002). Successful implementation of e-Learning Pedagogical considerations. Internet and Higher Education, 4, 287-299

[27] Hassanzadeh, A., Kanaani, F., \& Elahi, S. (2012). A model for measuring e-learning systems success in universities. Expert Systems with Applications, 39(12), 10959-10966.

[28] Helmi, A. (2002). An analysis on impetus of online education Curtin University of Technology, Western Australia. The Internet and Higher Education, 4, 243-253.

[29] Ibrahim, M., Rwegasira, K. S. P., \& Taher, A. (2007). Institutional Factors Affecting Students' Intentions to Withdraw From Distance Learning Programs in the Kingdom of Saudi Arabia the Case of the (AOU). Arab Open University

[30] Jan, A. U., \& Contreras, V. (2011). Technology acceptance model for the use of information technology in universities. Computers in Human Behavior, 27, 845-851.

[31] Johnson, R. D., Hornik, S., \& Salas, E. (2008). An empirical examination of factors contributing to the creation of successful e-learning environments. . International Journal of Human-Computer Studies, 66(5), 356-369.

[32] Khan, B. H. (2005). Learning features in an open, flexible, and distributed environment. Learning systems. Computers and Education, $53,761-774$

[33] Levy, Y. (2006). Assessing the value of eLearning systems. IGI Global.

Published By:

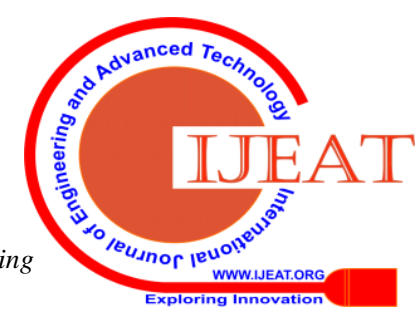


[34] Liaw, S. S., Huang, H. M., \& Chen, G. D. (2007). Surveying instructor and learner systems success in universities. . Expert Systems with Applications., 39, 10959-10966.

[35] Madina. (2014). Investigating the Success of E-Learning in Secondary Schools: The Case of the Kingdom of Bahrain. . (PhD Thesis. ), Brunel University, London.

[36] Malik, M. W. (2010). Factors Effecting Learner's Satisfaction Towards E-Learning: A Conceptual Framework. OIDA. Internationa Journal of Sustainable Development, 2(3), 77-82. .

[37] Masoumi, D. (2006). Critical factors for effective E-learning. Retrieved from http://www.e-quality-eu.org/pdf/seminar/e-Quality WS3 DMasoumi. pdf.

[38] Mbarek, R., \& Zaddem, F. (2013). The examination of factors affecting e-learning effectiveness. International Journal of Innovation and Applied Studies, 2(4), 423-435.

[39] McPherson, M. A., \& Nunes, J. M. (2008). Critical issues for e- learning delivery: what may seem obvious is not always put into practice. . Journal of computer assisted learning,, 24(5), 433-445.

[40] Ministry of Education Malaysia. (2012). Malaysia Education Blueprint 2013-2025. Putrajaya: Malaysia.

[41] Ministry of Finance Malaysia. (2013). Buku Maklum Balas Ke Atas Laporan Ketua Audit Negara Mengenai Penyata Kewangan Dan Pengurusan Kewangan Tahun 2013 Siri 3.

[42] Mosakhani, M., \& Jamporazmey, M. (2010). Introduce critical success factors (CSFs) of elearning for evaluating e-learning implementation success. . Paper presented at the International Conference on Educational and Information Technology

[43] Musa, M. A., \& Othman, M. S. (2012). Critical success factor in e-Learning: an examination of technology and student factors. International Journal of Advances in Engineering \& Technology, 3, 140.

[44] Nurul Islam, Martin Beer, \& Slack, F. (2015). E-Learning Challenges Faced by Academics in Higher Education: A Literature Review. Journal of Education and Training Studies, 3(5).

[45] Odunaike, S. A., Olugbara, O. O., Sunday O., \& Ojo, S. O. (2013). E-learning Implementation Critical Success Factors. Paper presented at the Proceedings of the International MultiConference of Engineers and Computer Scientists Hong Kong.

[46] Oliver, R., Herrington, J., \& Reeves, T. (2005). Creating authentic learning environments through blended learning approaches.

[47] Oppenheimer, T. (2003). The Flickering Mind: The False Promise of Technology in the Classroom and How Learning Can Be Saved. : Random House. NY.

[48] Owens, J. D., \& Price, L. (2010). Is E-Learning replacing the traditional Lecture? Education and Training Journal, 52(2), 128-139.

[49] Pituch, K. A., \& Lee, Y.-K. (2006). The influence of system characteristics on e-learninguse. Computer and Education, 47, 222-224

[50] Presley, A., \& Presley, T. (2009). Factors influencing student acceptance and use of academic portals. . Journal of computing in higher education, 21(3), 167-182.

[51] Recep Cakir, \& Solak, E. (2014). Exploring The Factors Influencing E-Learning Of Turkish EFL Learners Through TAM. . Turkish Online Journal of Distance Education 13(3), 79-87.

[52] Rockhart, J. F. (1979). Chief Executives Define Their Own Data Needs. Harvard Business Review, 57, 238-241.

[53] Romiszowski, P., \& Sikorski, A. (2005). Star-branched polymers in an adsorbing slit: A Monte Carlo study. The Journal of chemical physics, 123(10), 104905

[54] Selim, H. M. (2007). Critical success factors for e-learning acceptance: Confirmatory factor models. . Computers \& Education, 49, 396-413.

[55] Selim, H. S. (2007). E-learning critical success factors: an exploratory investigation of student perception. . International Journal of Technology Marketing, 2(2), 157-182.

[56] Shee, D. Y., \& Wang, Y.-S. (2008). Multi-criteria evaluation of the web-based e-learning system: A methodology based on learner satisfaction and its applications. Computers and Education, 50, 894-905.

[57] Sun, P. C., Tasi, R. J., Finger, G., Chen, Y. Y., \& Yeh, D. (2008). What drives a successful e- learning? An empirical investigation of the critical factors influencing learner satisfaction. . Computer and Education, 50, 1183-1202.

[58] Taha, M. (2013). Investigating Critical Factors Influencing the Success of E-Learning. Paper presented at the PhD Doctoral Symposium, Bahrain.
[59] Teo, T., Luan, W. S., Thammetar, T., \& Chattiwat, W. (2011) Assessing e-learning acceptance by university students in Thailand. Australasian Journal of Educational Technology, 27(8), 1356-1368.

[60] UNESCO. (2012). The Malaysia Education Policy Review.

[61] UNESCO. (2009). Review of Context and Structures for Education for Sustainable Development 2009.

[62] Volery, T., \& Lord, D. (2000). Critical success factors in online education. International Journal of Educational Management, 14(5) 216-223.

[63] Vrana, V., Zafiropoulos, C., \& Drogalas, G. (2006). Analysing students' attitudes towards the adoption of e-learning: The case of Technical Vocational Schools.Paper presented at the 3rd International Conference on Education and Economic Development, Prebeza, Greece

[64] Wagner, N., Hassanein, K., \& Head, M. (2008). Who is responsible for E-Learning Success in Higher Education?. A Stakeholders' Analysis. Educational Technology and Society, 11(3), 26-36.

[65] Wang, W.-T., \& Wang, C.C. (2009). An empirical study of instructor adoption of web based System for Secondary Schools. . Journal Educational Computing Research, 42, 63-78.

[66] Zewayed, N., Maynard, S., \& Murray, I. (2011). Factors Influencing Students' Acceptance of E-Learning at Secondary Schools. . Paper presented at the World Conference on E-Learning in Corporate Government, Healthcare, and Higher Education 2011

[67] Zhang, W., \& Cheng, Y. L. (2012). Quality Assurance in E-Learning PDPP Evaluation Model and its Application. The International Review of Research in Open and Distance Learning.

\section{APPENDIX 1}

SOURCES OF PUBLICATION AND CITATION NUMBER

Publisher Reference Year Cites*

Center for

Promoting Ideas, Frimpon,

201222

USA

Ebscohost

Al-Fadhli,

$2011 \quad 14$

Sun et al.

2008

Jan, A. U., \& Contreras, V. 2011

Wang, W. T., \& Wang, C.

C.

Pituch \& Lee 2006

755

Abu Sneineh \& Zairi, $\quad 2010 \quad 14$

Shee dan Wang, 2008346

Elsevier Ltd. Hassanzadeh, A., Kanaani, 2012151

F., \& Elahi, S.

$2008 \quad 388$

Johnson et al., 2008

Chen dan Tseng, 2012

Liaw, S. S., Huang, H. M., 2007

\& Chen, G. D.

Govindasamy, T. $2002 \quad 890$

Bhuasiri, W. et al. $\quad 2012 \quad 378$

Selim H.M. $\quad 2007 \quad 880$

Inderscience $\quad$ Selim $\quad 2007 \quad 62$

Publishers $\quad$ Malik, $2010 \quad 19$

Springer $\quad$ Presley dan Presley, $2009 \quad 28$

European Journals Inc

Chokri,

201213

SAGE

Al-Fadhli

$2008 \quad 23$

Publications Inc.

Wang dan Wang,

$209 \quad 258$

Friedrich and Horn, 2010

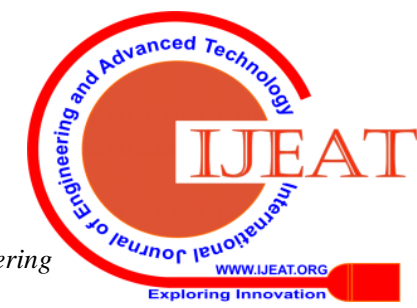




\begin{tabular}{|c|c|c|c|}
\hline Emerald Group & Owens dan Price, & 2010 & 35 \\
\hline Publishing Ltd. & Volery and Lord, & 2000 & 875 \\
\hline & $\begin{array}{l}\text { Musa, M. A., \& Othman, M. } \\
\text { S. }\end{array}$ & 2012 & 18 \\
\hline Researchgate & Broadley & 2007 & 11 \\
\hline & $\begin{array}{l}\text { Al-Ammari, Jaflah, and } \\
\text { Sharifa Hamad. }\end{array}$ & 2008 & 25 \\
\hline Wiley & Abdel-Wahab, & 2008 & 76 \\
\hline wiley & Ahmed, & 2010 & 129 \\
\hline curtin.edu & Goi dan Ng, & 2009 & 89 \\
\hline ascilite.org.au & Teo et al., & 2011 & 29 \\
\hline $\begin{array}{l}\text { The JALT CALL } \\
\text { SIG }\end{array}$ & Fageeh & 2011 & 19 \\
\hline & $\begin{array}{l}\text { Ali, A., Ramay, M. I., \& } \\
\text { Shahzad, M. }\end{array}$ & 2011 & 81 \\
\hline & FitzPatrick (2012) & 2012 & 16 \\
\hline ERIC & $\begin{array}{l}\text { Sami Alhomod \& Mohd } \\
\text { Mudasir Shafi }\end{array}$ & 2013 & 33 \\
\hline & $\begin{array}{l}\text { Recep Cakir \& Ekrem } \\
\text { Solak }\end{array}$ & 2014 & 13 \\
\hline & Abbad et al., & 2009 & 185 \\
\hline $\begin{array}{l}\text { Blackwell } \\
\text { Publishing Inc. }\end{array}$ & $\begin{array}{l}\text { McPherson, M. A., \& } \\
\text { Nunes, J. M. }\end{array}$ & 2008 & 101 \\
\hline & Fuad A. A.Trayek \& & & \\
\hline DergiPark & $\begin{array}{l}\text { Sharifah Sariah Syed } \\
\text { Hassan }\end{array}$ & 2013 & 6 \\
\hline $\begin{array}{l}\text { Moment } \\
\text { Publications }\end{array}$ & $\begin{array}{l}\text { Mohammed Simko } \\
\text { Abdullah \& Mehmet } \\
\text { Toycan }\end{array}$ & 2018 & 1 \\
\hline RedFame & $\begin{array}{l}\text { Nurul Islam, Martin Beer, } \\
\text { Frances Slack }\end{array}$ & 2015 & 22 \\
\hline $\begin{array}{l}\text { Association for } \\
\text { the Advancement } \\
\text { of Computing in } \\
\text { Education } \\
\text { (AACE) }\end{array}$ & Zewayed et al., & 2011 & 3 \\
\hline & Mosakhani \& Jamporazmey & 2010 & 33 \\
\hline ieeexplore & Farn-Shing Chen, & & \\
\hline & Tsai-Hsiu Chen & & $J$ \\
\hline
\end{tabular}

\section{APPENDIX 2}

NUMBER OF PAPERS IN EACH JOURNAL

\begin{tabular}{ll}
\hline Journal Name & $\begin{array}{l}\text { Number of } \\
\text { papers }\end{array}$ \\
\hline $\begin{array}{l}\text { Computer and Education } \\
\text { Turkish Online Journal of Distance Education }\end{array}$ & 7 \\
$\begin{array}{l}\text { Journal Educational Computing Research } \\
\text { American International Journal of }\end{array}$ & 2 \\
$\quad$ Contemporary Research & 1 \\
Australasian Journal of Educational & \\
$\quad$ Technology & 1 \\
Computers in Human Behavior & 1 \\
Decision Sciences Journal of Innovative & 1 \\
$\quad$ Education & 1 \\
Education and Training & 1 \\
E-Learning and Digital Media & 1 \\
EURASIA Journal of Mathematics, Science and & 1
\end{tabular}

\section{Technology Education}

European Scientific Journal

Evaluation and Program Planning

Expert Systems with Applications

International Encyclopedia of Education

International Journal of Advances in

$$
\text { Engineering \& Technology }
$$

International journal of educational management

International Journal of Human-Computer Studies

International Journal of Instructional Media. $\quad 1$

International Journal of Sustainable

$$
\text { Development }
$$

International Journal of Teaching and Learning in Higher Education

International Journal of Technology Marketing 1

International Review of Research in Open and Distance Learning

Internet and Higher Education $\quad 1$

Journal of Computer Assisted Learning, 1

Journal of computing in higher education 1

Journal of Education and Training Studies 1

The JALT CALL Journal

NUMBER OF PAPERS IN EACH CONFERENCE

\begin{tabular}{cc}
\hline Conference & $\begin{array}{l}\text { No of } \\
\text { papers }\end{array}$ \\
\hline IEEE 2010 International Conference on Educational and
\end{tabular}

IEEE 2010 International Conference on Educational and Information Technology

International Education Research Conference - AARE 1 2007

2nd International Conference and Exhibition for Zain 1

E-learning Center (2008)

US-China Education Review A 9

2009 International Conference on Education Technology

and Training (ETT 2009)

E-Learn: World Conference on E-Learning in Corporate, Government, Healthcare, and Higher Education (2011) 